\title{
Modeling the reliability of the recycled water supply system in the conditions of global warming
}

\author{
Oleksiy Nazarenko \\ Zaporozhye State Engineering Academy \\ Dobrolyubova str. 22, Zaporozhye, Ukraine, 69006 \\ alexnazar75.an@gmail.com, orcid.org/0000-0003-3738-1129
}

The manuscript was received on 14.01.2018 and was accepted after revision for publication on 24.03.2018

DOI: 10.31493/tit1811.0201

\begin{abstract}
The issues of re-used water for recreational purposes were studied. The organic system of the enterprise may be a recycled system of water supply, hermetically sealed and equipped with automatic sensors, in every sense. It is also appropriate to use the remote controlling for thermal engineering parameters at factory sections using GPS modules. The importance of the corporate accent lies in the creation of social responsibility for service-managers and mechanics for each resource saving actions and future economic preferences.
\end{abstract}

The most perspective and socially motivated direction of recycling is the modeling of balance of different water flows, considering the quality of chemical components.

Currently, citizens and the administration of technoparks evaluate the clean water for such indicators:

- water safety (sanitary and epidemiological requirements);

- availability of water (quantity and quality);

- stability water quality (water for ecosystems, water for health, water for sustainable

development);

- climate change and water security.

To conform these indicators, an experiments were undertaken for different work modes of enterprise equipment.

So to determine the optimal amount of fresh water supply, the second order of central orthogonal compositional planning is used.

Mathematic model was obtained during scientific experiment.

The system modeling considering hardness of water supply $(1,5 \ldots 10,5 \mathrm{~m}$-q/l), the water alkalinity $(1,5 \ldots 10 \mathrm{~m}-\mathrm{q} / \mathrm{l})$ gives the predictive data on the

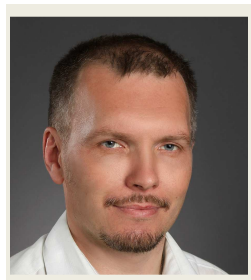

Oleksiy Nazarenko

Associate Professor of the Department of Heat and Power Engineering and Hydropower Ph.D., Ass. Prof.

permissible coefficient of circulating water evaporation.

On the basis of this simulation, it is advisable to recommend the preparation of artificial recharge supply with water hardness of $1,5 \mathrm{~m}-\mathrm{q} / \mathrm{l}$ at the enterprises. It will allow the system to operate at evaporation coefficient of 2,55 and save fresh water volume, equal to the production cycle.

So the using of agricultural waste (chitosan) shows the possibility of its using for local sewage water cleaning of industrial cycles.

The same solution can be used to feed vegetable and ornamental crops, in the local agricultural landscape of the enterprise. Development of the subsidiary production, allows to expand the range of production and to improve the company's image.

Key words: balance, water consumption coefficient, reverse water, evaporation coefficient, artificial supply system, hardness.

\section{INTRODUCTION}

Certainly, an organic system of the enterprise may be a recycled system of water supply, hermetically sealed and equipped with automatic sensors, in every sense. It is also appropriate the remote controlling for thermal 
engineering parameters at factory sections using GPS modules. The importance of the corporate accent lies in the creation of social responsibility for service-managers and mechanics for each resource saving actions and future economic preferences.

\section{MATERIALS AND METHODS}

To optimize artificial supply system regulation through introduction of GSM means by engineering calculation of water chemical mode.

\section{RESULTS AND EXPLANATION}

The most perspective and socially motivated direction of recycling is the modeling of different water flows balance, with considering the quality of chemical components [2, 4, 7, 8]. Currently, citizens and the administration of technoparks evaluate the clean water by such indicators:

- water safety (sanitary and epidemiological requirements);

- availability of water (quantity and quality);

- water quality stability (water for ecosystems, water for health, water for sustainable development);

- climate changes and water security.

To conform to such indicators, an experiment is undertaken for different work modes of enterprise equipment $[3,5,6]$.

For example, to ensure the productivity of agglomeration factories at Zaporozhye enterprises at ambient temperatures during the transition and the summer season $\left(8 \ldots 32^{\circ} \mathrm{C}\right)$ and the hardness of the supply water $(2,5 \ldots 3,6 \mathrm{~m}$ $\mathrm{q} / \mathrm{l})$, which is typical for the Dnieper River (Zaporozhye), fresh water must be compensated. So to determine the optimal amount of fresh water supply, the second order of central orthogonal compositional planning is used. The advantage of such model planning is the possibility of sequential variation by each active parameter ( 2 parameters) at modeling $[6,11-13]$.

Mathematic model was obtained during scientific experiment:

$$
\begin{aligned}
& Y=5,092785-0,28167 X_{1}+1,2325 X_{2}- \\
& -0,009 X_{1}^{2}-0,7265 X_{2}^{2}-0,04375 X_{1} X_{2}
\end{aligned}
$$

where $X_{1}$ - air temperature, ${ }^{\circ} \mathrm{C} ; X_{2}$ - hardness of supply water, m-q/l; $Y-$ system artificial recharge, $\mathrm{m}^{3} / \mathrm{h}$.

Applying the graphical interpretation of the curves lines, we get a graphical diagram of the productivity effect of the work cycle, as a result of system artificial recharge system (Fig.1).

\section{Graphical curves of optimization parameters}
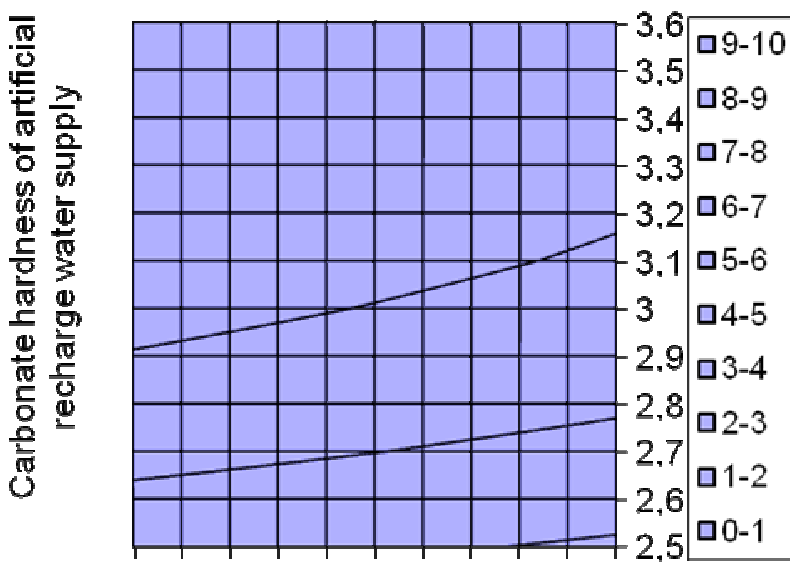

$810,42,85,27,62022,94,87,29,632$

Air temperature

Fig.1. Graphical interpretation of the air temperature influence on the artificial recharge water supply of the circulating system

Thus, applying the second order experiment, we obtain a working tool for determining the value of the water supply artificial recharge of the recycling at the enterprises $[9,10]$.

Analyzing the graph, we understand that at air temperature of $32{ }^{\circ} \mathrm{C}$ and carbonate hardness of $2,5 \mathrm{~m}-\mathrm{q} / \mathrm{L}$, the artificial recharge of the supply system is $1 \mathrm{~m}^{3} / \mathrm{h}$. It should be considered that water saving can amount to 100,000 hrn per year for one cycle, if each enterprise has proper instrumentation and regular training of personal.

In this situation it will be actually the calculation of the risks for technological processes (the century of global warming) $[15,16]$, considering the effect of carbonate anion accumulation in pipes, leading to capacity reduction of pipe; in the worst case, to plugging of 
pipelines leading to hydraulic resistance increasing and energy overexpenditure of carriers at separate sectors. The system modeling considering hardness of water supply $(1,5 \ldots 10,5 \mathrm{~m}-\mathrm{q} / \mathrm{l})$, the water alkalinity $(1,5 \ldots 10 \mathrm{~m}-\mathrm{q} / \mathrm{l})$ gives the predictive data on the permissible coefficient of circulating water evaporation (Fig.2).

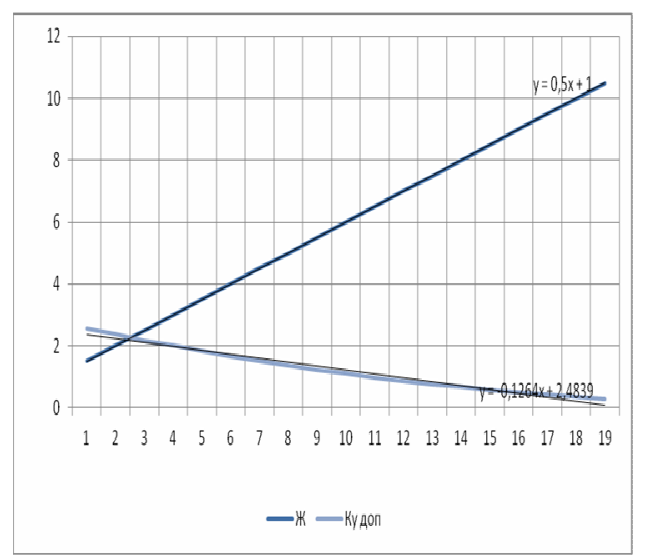

Fig.2. Water hardness effect of on the changing permissible water evaporation coefficient

On the basis of this simulation, it is advisable to recommend the preparation of artificial recharge supply with water hardness of $1,5 \mathrm{~m}$ $\mathrm{q} / \mathrm{l}$ at the enterprises. It will allow the system to operate at evaporation coefficient of 2,55 and save fresh water volume [5], equal to the production cycle $[17,18]$. However, hardness increasing to $5,5 \mathrm{~m}-\mathrm{q} / \mathrm{l}$ leads to decreasing evaporation coefficient of the system to 1,23 value. Further disregard of water conditioning leads to the water costs doubling, and to unplanned pipeline cleaning also.

Climate change will eventually lead to a change in the pattern of the hydrological cycle in space and time. Then it may lead to increasing of extreme weather phenome such as floods, droughts and hurricanes. The areas of food production, industrial development, urban water supply, recreation and entertainment, ecosystem services represent future potential risks; there may be an increase in competition and conflicts based on water quality in a regional, national or international scale.

The varying of chemical parameters of the water balance also represents novelty and technical interest. The water oxidability analy- ses testify of the necessity of the system purification. As a consequence, the whole water supply system will operate properly. The other circulating water evaporation coefficients, indicate the feasibility of reagent treatment of water to stabilize the water-chemical mode of the system (Table 1). The experiment was carried out to evaluate the limitations of the work of dirty recycling units [3].

Table 1. The water chemical mode parameters of the water supply system

\begin{tabular}{|c|l|c|c|c|c|c|}
\hline № & Parameter & \multicolumn{5}{|c|}{ Values } \\
\hline 1 & $\begin{array}{l}\text { Oxidability, } \\
\text { mg/l }\end{array}$ & 9 & 25 & 35 & 75 & 480 \\
\hline 2 & $\begin{array}{l}\text { Carbonate } \\
\text { hardness, m- } \\
\text { q/l }\end{array}$ & 3,74 & 5,48 & 6,14 & 11,9 & 60,01 \\
\hline 3 & $\begin{array}{l}\text { Supply of } \\
\text { the system, } \\
\mathrm{m}^{3} / \mathrm{h}\end{array}$ & 0,04 & 0,03 & 0,02 & 0,01 & 0,013 \\
\hline 4 & $\begin{array}{l}\text { Water evap- } \\
\text { oration coef- } \\
\text { ficient }\end{array}$ & 1,41 & 2,069 & 2,33 & 4,515 & 22,647 \\
\hline
\end{tabular}

Using mathematical modeling of the received data we get mathematical model of water oxidizing from water supply system conditioning

$$
\begin{aligned}
Y= & 12,854+0,553 X_{1}-1,302 X_{2}-5,401 X_{3}+ \\
& +2,264 X_{1}^{2}-7,883 X_{2}^{2}+0,074 X_{3}^{2}+ \\
& +3,983 X_{1} X_{2}+0,335 X_{1} X_{3}+4,894 X_{2} X_{3},
\end{aligned}
$$

where $X_{1}$ - water oxidizing, $\mathrm{mg} / \mathrm{l} ; X_{2}$ - conditioning of water supply system, $\mathrm{m}^{3} / \mathrm{h} ; Y-$ water evaporation coefficient in the system.

One of the main conditions of blast furnace working is the providing it with cooling pipe from surface through expected temperature overfall.

For example, to provide furnace work productivity at Zaporozhsky enterprise at temperature overfall $\left(4 \ldots 20{ }^{\circ} \mathrm{C}\right)$ and cooling water expense $\left(2,06 \ldots 0,4 \mathrm{~m}^{3} / \mathrm{h}\right)$, which are peculiar for Dnieper river (Zaporozhye region)it is necessary fresh water supply. The calculation shows that when water preparation is organized properly the expense of cooling water is 
$0,4 \mathrm{~m}^{3} / \mathrm{h}$ instead of $1,6 \mathrm{~m}^{3} / \mathrm{h}$ (annual equivalent is $14016 \mathrm{~m}^{3}$ on one of the cooling elements).

It is mathematical modeling which allows to find out «weak parts» in water supply process and to regulate equipment. Economic progress makes us use the newest technologies and equipment save resources and decrease cost pries at every enterprises.

So the using of agricultural waste (chitosan) shows the possibility of its using for local sewage water cleaning of industrial cycles.

To conduct the research standard procedure of water settling in suspended grainy layer was used.

Grinding of chitosan to $0,3 \mathrm{~mm}$ was carried out and laboratory capacity was filled with it up to $30 \mathrm{sm}$.

Local treatment of waste water with chitosan (amount of $45 \mathrm{mg} / \mathrm{l}$ ) with capacity of 2,9 $\mathrm{x} 10^{-3} \mathrm{~g}$ after 180 minutes of settling, reduces $\mathrm{pH}$ to 5,6 ; hardness increases to $5,6 \mathrm{mq} / \mathrm{l}$, the salt content reduced to $380 \mathrm{mg} / \mathrm{l}$, the iron concentration rises to $1,2 \mathrm{mg} / \mathrm{l}$. The same solution can be used to feed vegetable and ornamental crops, in the local agricultural landscape of the enterprise. Development of the subsidiary production, allows to expand the range of production and to improve the company's image. Standard technology for settling water in a suspended granular layer was used. Chitosan was milled to $0,3 \mathrm{~mm}$ fraction and laboratory column was filled to a height of $30 \mathrm{~cm}[19]$. Then it was filled with the test solution and exposition from 15 minutes to 2580 minutes was carried out. The results of the studies are shown in Table 2.

Table 2. The results of investigation of wastewater treatment with chitosan, fractions of $3 \mathrm{~mm}$

\begin{tabular}{|c|c|c|c|c|c|}
\hline $\begin{array}{c}\text { № } \\
\text { п/п }\end{array}$ & $\mathrm{T}, \min$ & $\begin{array}{c}\mathrm{M}, \\
\mathrm{mg} / \mathrm{l}\end{array}$ & $\begin{array}{c}\mathrm{H}, \mathrm{m}- \\
\mathrm{q} / \mathrm{l}\end{array}$ & $\begin{array}{c}\mathrm{R}, \mathrm{m}- \\
\mathrm{q} / \mathrm{l}\end{array}$ & $\mathrm{S}, \mathrm{mg} / \mathrm{l}$ \\
\hline 1 & 30 & 2 & 5,34 & 2,5 & 480 \\
\hline 2 & 60 & 15 & 6,06 & 5,1 & 750 \\
\hline 3 & 90 & 50 & 7,15 & 6,2 & 850 \\
\hline 4 & 150 & 72 & 10,8 & 4,1 & 905 \\
\hline 5 & 1140 & 200 & 15 & 4,8 & 978 \\
\hline 6 & 1380 & 212 & 17,4 & 5,6 & 984 \\
\hline 7 & 2580 & 225 & 21,25 & 7,75 & 990 \\
\hline
\end{tabular}

During the periods of water quality measurements: turbidity, water hardness, alkalinity sensors, express test for the determination of iron in water, sensors of oxidizability, $\mathrm{pH}$, measurements potential of the reductionoxidation were used. The temperature of the experiments ranged from 12 to $16{ }^{\circ} \mathrm{C}$. Every 30 minutes, the solution was drained and measured. The data indicate on productivity of water treatment at 60 and 90 minutes, after which the stage of chitosan saturation and increase of water hardness and salt content is observed. It should be noted that such processes are actual in the case of water re-using for recreational purposes and subsidiary production. Apparently, the amino- acids of chitin enter into force. Due to their reactivity to interact they form complex molecular bonds with salt molecules, which leads to a process of solution saturation. To get the full picture of process, we need to make a spectral analysis of the wastewater components.

Because of the complexity of conducting such analysis in field conditions, it is necessary to apply water quality sensors at working and peak modes.

At the same time the analysis of ground hazelnut with fraction of $1,5 \mathrm{~mm}$ diameter; prepared by mechanical absorption was conducted (Table 3). The technology of experiment is similar to the previous one [20].

Table 3. Research of wastewater treatment with hazelnut grinding, fractions of $1,5 \mathrm{~mm}$

\begin{tabular}{|c|c|c|c|c|c|}
\hline $\begin{array}{c}\text { № } \\
\Pi / \Pi\end{array}$ & $\begin{array}{c}\mathrm{T}, \\
\mathrm{min}\end{array}$ & $\begin{array}{c}\mathrm{M}, \\
\mathrm{mg} / \mathrm{l}\end{array}$ & $\begin{array}{c}\mathrm{H}_{\mathrm{Ca}}, \\
\mathrm{m}-\mathrm{q} / \mathrm{l}\end{array}$ & $\begin{array}{c}\mathrm{R}, \mathrm{m}- \\
\mathrm{q} / \mathrm{l}\end{array}$ & $\begin{array}{c}\mathrm{S}, \\
\mathrm{mg} / \mathrm{l}\end{array}$ \\
\hline 1 & 0 & 2 & 1,2 & 2 & 220 \\
\hline 2 & 40 & 3,2 & 1,36 & 2,7 & 248 \\
\hline 3 & 60 & 65 & 1,7 & 2,8 & 285 \\
\hline 4 & 120 & 85 & 2,42 & 3,5 & 352 \\
\hline 5 & 180 & 180 & 2,88 & 4 & 380 \\
\hline 6 & 279 & 205 & 3,3 & 4,2 & 395 \\
\hline 7 & 372 & 215 & 3,56 & 4,6 & 435 \\
\hline 8 & 1390 & 270 & 3,78 & 5,1 & 470 \\
\hline 9 & 1440 & 274 & 3,92 & 5,8 & 486 \\
\hline 10 & 1480 & 248 & 4,06 & 5,95 & 492 \\
\hline 11 & 1500 & 245 & 4,38 & 6,12 & 521 \\
\hline 12 & 1560 & 235 & 4,42 & 6,22 & 532 \\
\hline 13 & 1620 & 218 & 4,56 & 6,37 & 562 \\
\hline 14 & 1719 & 211 & 4,66 & 6,4 & 574 \\
\hline 15 & 1812 & 210 & 4,96 & 6,5 & 581 \\
\hline
\end{tabular}


The temperature of the experiments ranged from $14^{\circ}$ to $22^{\circ} \mathrm{C}$. Every 30 minutes, solution sample was taken and the chemical indicators were measured. The data indicate on productivity of water treatment at 60 and 90 minutes, after which the stage of wastewater saturation with fulvic acids is observed and the water rigidity and salt content increase.

The physical-chemical properties of the studied material are interesting. The results of mechanical adsorption with unbroken hazelnut shell, with fraction diameter of $14 \mathrm{~mm}$. The results are shown in Table.4. The technology of the experiment is similar to previous studies. List of measuring equipment is similar.

Table 4. Research of wastewater treatment with hazelnut grinding, fractions of $14 \mathrm{~mm}$

\begin{tabular}{|c|c|c|c|c|c|}
\hline $\begin{array}{c}\text { № } \\
\text { П/П }\end{array}$ & $\underset{\min }{\mathrm{T}}$ & $\begin{array}{c}\mathrm{M}, \\
\mathrm{mg} / \mathrm{l}\end{array}$ & $\begin{array}{l}\mathrm{H}_{\mathrm{Ca}}, \\
\mathrm{m}-\mathrm{q} / \mathrm{l}\end{array}$ & $\mathrm{R}, \mathrm{m}-\mathrm{q} / \mathrm{l}$ & $\mathrm{S}, \mathrm{mg} / \mathrm{l}$ \\
\hline 1 & 0 & 2,5 & 15,6 & 12,5 & 1110 \\
\hline 2 & 60 & 2,7 & 14,4 & 16,5 & 950 \\
\hline 3 & 120 & 3,1 & 9,3 & 19,8 & 870 \\
\hline 4 & 1320 & 2.9 & 6,6 & 10,2 & 910 \\
\hline 5 & 1587 & 2,7 & 6,8 & 11,9 & 780 \\
\hline 6 & 1647 & 2,65 & 7,8 & 10,3 & 750 \\
\hline 7 & 2784 & 3,2 & 7,62 & 9,8 & 720 \\
\hline 8 & 2864 & 5 & 5,86 & 9,5 & 683 \\
\hline 9 & 3034 & 4,5 & 5,1 & 9,1 & 673 \\
\hline 10 & 4184 & 5,2 & 5,02 & 11,5 & 757 \\
\hline 11 & 4329 & 5,3 & 5,08 & 10,8 & 732 \\
\hline
\end{tabular}

The temperature of the experiments ranged from $12^{\circ}$ to $19^{\circ} \mathrm{C}$. Every 30 minutes, solution sample was taken and the chemical indicators were measured. The data indicate on productivity of water treatment for $1320 \mathrm{~min}$. Then, the stage of waste-water with products of shell biomaterial decomposition and increasing of water alkalinity and salinity are observed.

Besides the necessity of controlling the water-conditioning process, it is important to control the reference indicators for each part of the technological process, mainly in the remote mode.

The process of replenishment of the technological process losses represents the operational tasks of each power engineering enterprise [19]. At the same times, the research of the possibility and feasibility of the enterprises water use increasing is very important for resource conservation. The use of reclaimed water after local treatment for increasing the soil productivity is relatively next step in agronomy. The use of enriched water with chitosan, by drip irrigation of plants, (process of 14 days), shows green mass increasing in the stem from $4,5 \mathrm{~cm}$ to $8,5 \mathrm{~cm}$ (in $188 \%$ ); the leaf diameter increasing in 1,3 times.

It may be actually, the use of other wastes for adsorption purposes that is extremely necessary in finding ways of resource saving.

In the case of chitosan using $(4,5 \%)$, we observe slight decrease of hardness and alkalinity in the reclaimed water in the interval of 60-270 min. In the subsequent period, the saturation of the secondary water with amino acids is noticeable, which affects the water. It is likely that the saturation processes is associated with the molecule valence and free reactivity of the solution. In the measure of interaction (the length of the contact), the molecules of the substance become active, the ionic strength of the solution increases. The controlled course of the process is actual for this investigation. In the absence of setted tasks for the experiment, the valence of the solution may be changed through the molecular components absorption from the solution. In some cases, when complex mixtures are formed, theoretical limitations may be omitted and the additivity rule may be applied [20].

Vapor pressure of solutions containing electrolytes, $\left(2 \mathrm{KC} 1+\mathrm{MgCl}_{2}\right)$, was studied in a wide range of concentrations at $25^{\circ} \mathrm{C}$. The solution in the case of 0,5 molar solution of double salt, $\mathrm{K}_{2} \mathrm{MgCl}_{4}$ has low pressure pairs $\Delta p / p_{\mathrm{o}}=0,06040$; the concentration of potassium chloride is $1 \mathrm{~mol}$, at which the concentration and absence of other solutions lower the vapor pressure, $\Delta p / p_{\mathrm{o}}=0,03182$. Similarly, for 0,5 moles of magnesium chloride, $\Delta p / p_{0}=$ $=0,02525$. If we add these two components, we'll get a calculated drop in vapor pressure $\Delta p / p_{0}=0,05707$, value that differs by $5,5 \%$ of the measured value. The best option can be obtained by a little elaboration, which is illustrated by: solution $\left(2 \mathrm{KCl}+\mathrm{MgCl}_{2}\right)$ with total ionic strength of 2,5 ; using decrease in the 
pressure of the molar vapor components at total ionic strength, $\Delta p /\left(m p_{\mathrm{o}}\right)=0,03195$ for potassium chloride; 0,05530 for magnesium chloride; the ratio in the $\Delta p / p_{0}$ mixture is 0,03195 (potassium chloride) and 0,02765 (magnesium chloride) with estimated value of 0,0560 , which differs from the actual value only by $1 \ldots 3 \%$.

In carrying out the experiment, it is important to use spectral analysis to predict the course of the chemical reaction and the final formula of the derivative [6].

On the basis of the obtained experimental results, it is useful to get mixed materials for the protocol experiment results.

In this case, the discrepancy between theoretical and practical values may be minimal. In similar way, such combinations of mixtures were performed experimentally: chitin (23\%), protein $(35 \%)$, melanoprotein $(42 \%)$. In testing the experiment, the following results were obtained (Table 5):

Table 5. Research of wastewater treatment with chitosan mix №1, fractions of $2 \mathrm{~mm}$

\begin{tabular}{|c|c|c|c|c|c|}
\hline $\begin{array}{c}\text { № } \\
\text { п/п }\end{array}$ & T, min & $\begin{array}{c}\text { M, } \\
\mathrm{mg} / 1\end{array}$ & $\begin{array}{c}\mathrm{H}, \mathrm{m}- \\
\mathrm{q} / \mathrm{l}\end{array}$ & $\begin{array}{c}\mathrm{A}, \mathrm{m}- \\
\mathrm{q} / \mathrm{l}\end{array}$ & $\mathrm{S}, \mathrm{mg} / \mathrm{l}$ \\
\hline 1 & 30 & 2 & 5,34 & 2,5 & 480 \\
\hline 2 & 60 & 4 & 5,11 & 2,6 & 430 \\
\hline 3 & 90 & 4,5 & 5,05 & 2,4 & 379 \\
\hline 4 & 150 & 5,1 & 4,8 & 2,3 & 411 \\
\hline 5 & 1140 & 5,45 & 5,2 & 2,4 & 428 \\
\hline 6 & 1380 & 7 & 5,45 & 2,45 & 475 \\
\hline 7 & 2580 & 7,9 & 5,65 & 2,73 & 598 \\
\hline
\end{tabular}

It is also possible to obtain mix in the following form: protein $(12 \%)$, glucose $(80 \%)$, mannose $(3 \%)$, galactose $(2 \%)$, xylose $(0,5 \%)$, ash $(2,5 \%)$ (Table 6). The experimental data were analyzed.

Analysis of the obtained data shows that mix № 2 (protein (12\%), glucose $(80 \%)$, mannose $(3 \%)$, galactose $(2 \%)$, xylose $(0,5 \%)$, ash $(2,5 \%))$ is $20 \%$ more productive than mix № 1 (chitin $(23 \%)$, protein $(35 \%)$, melanoprotein $(42 \%))$ in the time interval of $30 \ldots 150 \mathrm{~min}$. Indicator readings of water (rigidity, alkalinity, salt content) are reduced by $12 \ldots 23 \%$.
Table 6. Research of wastewater treatment with protein mix №2, fractions of $2 \mathrm{~mm}$

\begin{tabular}{|c|c|c|c|c|c|}
\hline $\begin{array}{c}\text { № } \\
\text { p/p }\end{array}$ & T,min & $\begin{array}{c}\mathrm{M}, \\
\mathrm{mg} / \mathrm{l}\end{array}$ & $\begin{array}{c}\mathrm{H}, \mathrm{m}- \\
\mathrm{q} / \mathrm{l}\end{array}$ & $\begin{array}{c}\mathrm{A}, \\
\mathrm{mg}- \\
\mathrm{q} / \mathrm{l}\end{array}$ & S, mg/l \\
\hline 1 & 30 & 2 & 5,34 & 2,5 & 480 \\
\hline 2 & 60 & 3,7 & 5,08 & 2,35 & 415 \\
\hline 3 & 90 & 4,2 & 5,11 & 2,32 & 425 \\
\hline 4 & 150 & 4,38 & 5,28 & 2,4 & 481 \\
\hline 5 & 1140 & 4,62 & 5,35 & 2,43 & 512 \\
\hline 6 & 1380 & 4,79 & 5,7 & 2,48 & 574 \\
\hline 7 & 2580 & 5,3 & 7,1 & 2,61 & 582 \\
\hline
\end{tabular}

Practice recommends the development of adsorption mixes for obtaining the desired result in cleaning efficiency [15]. It is extremely important to solve the problem of resource-saving, especially in the case of technological chains closing. Utilization accent can express the sewage of the enterprise, which represents production reserves for increasing competitiveness:

- as a secondary resource carrying a thermal potential;

- the reserve of the enterprise, which after local cleaning expands the products in the agricultural segment.

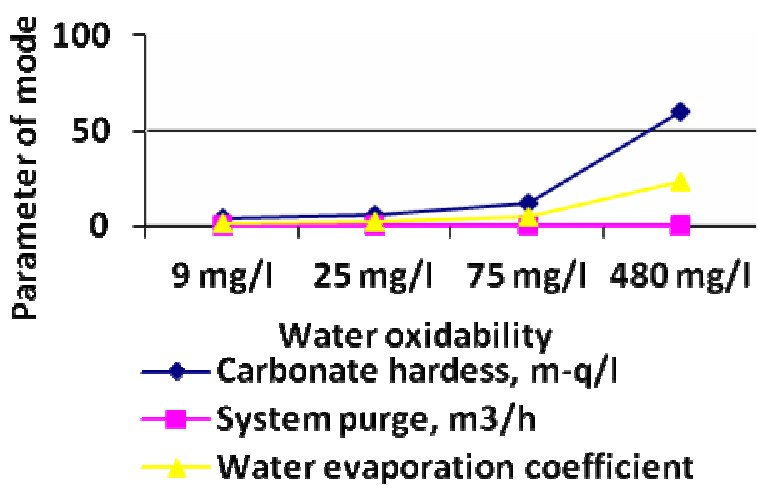

Fig.3. The effect of the water oxidability change on the water evaporation coefficient

\section{CONCLUSIONS}

1. Planned introduction of instrumentation and technical indicators saves to 100,000 uah/year on each production cycle.

2. The technological process is possible at a 2,25 evaporation rate, but requires careful at- 
tention and readiness of the reagent solution treatment.

3. Mathematical model of the water evaporation coefficient of the system is obtained.

4. It is possible to use reversed water in production with purging increasing of the system to $0,015 \mathrm{~m}^{3} / \mathrm{h}$.

5. It is possible to use chitosan in amount of $45 \mathrm{mg} / \mathrm{l}$, with capacity of $2,9 \times 10^{-3} \mathrm{~g}$ which after 180 minutes of settling reduces the $\mathrm{pH}$ to 5,6 ; the hardness is increased to $5,6 \mathrm{~m}-\mathrm{q} / \mathrm{l}$, the salt content is reduced to $380 \mathrm{mg} / \mathrm{l}$.

6 . The solution can be used to feed vegetable and ornamental crops in the local agricultural landscape of the enterprise. The use of adjacent production facilities allows to expand the range of products and to improve the company's image.

\section{REFERENCES}

1. Pantelyat G.S., 1982. Issledovanie, razrabotka i osvoenie kompleksov zamknutyh system oborotnogo vodosnabgenia osnovnyh proizvodstv metallurgicheskyx predpriztyu bez sbrosa stochnyh vod v vodoem. Zamknutye systemy vodnogo hozyaistva promyslennyx predpriztiy i rayonov. MDNTP, Moskow, Znaniye, 33-39 (in Russian).

2. Tovazhnyanskiy L.L., Gotlinskaya A.P., 2005. Procesy y aparaty himichnoy technology. Procesy y aparaty himichnoy technologyi: [pidrucnik v 2-h chastinah. Harkiv, NTU HPY, 532 (in Russian).

3. Drozdova G.G., 2004. Metodika opredeleniya efectivnisti zatrat na ohranu prirody. Kyiv, KGTU, 12 (in Russian).

4. Nazarenko O.M., Kuzmenko A.A., 2017. Benchmarking dzerel zhivilnoy vody. Zbirnyk naukovich prats, Naukovy visnuk budivniztva Harkiv, HNUBA, 111-117 (in Ukrainian).

5. Hosocava, Tezyo, Ivasaki, 1999. Kurita rukovodstvo po vodopodgotovke. Water Industries LTD, 2d izdanie, 244 (in Russian).

6. Nazarenko O.M., 2018. Ryzyk management vodokorystuvachiv richky Dnipro. Monografia. Zaporozhye, 203 (in Ukrainian).

7. Semenov O.E., 2011. Vvedenie v experimentalnuyu meteorologiyu i klimatologiy u peschanych byr. Almaty, 187 (in Russian).

8. Shypulin V.D., 2010. Osnovnye prinstipy geoinformatsionnyh system. Harkiv, HNAGH, 337 (in Russian).
9. Alekseev V.I., 2003. Proektirovanie sooruzheny pererabotki I utilizatii stochnych vod s ispolzovaniem elementov computernych informatsionnyh technologiy. Moskow, Izd-vo ASV, 176 (in Russian).

10. Basos N.Ju., 2010. Biocentrichesko-setevaja struktura urbanizacii landshaftov (na primere kontinental'nyh i primors'kih gorodov). Saarbrucken, Lambert-Academic Publishers, 92 (in Russian).

11. Patent UA №123556, MPK, F17D5/02/2006. 01. Sistema viddalenogo monitoringu parametriv teplonosija $\mathrm{u}$ dvotrubnih teplovih merezhah. Nazarenko O.M., Bichenko K.O. No.U201710667, zajavl.02.11.2017, opubl. 26.02.18, Bjul.4 (in Ukrainian).

12. Horuzhij P.D., 2003. Resursosberegajuchi tehnologiï vodopostachannja Kyiv, Agrarna nauka, 534 (in Ukrainian).

13. Pierchurski F., 2005. Straty wody I sposoby ich obnizahia Ochrona Srodowiska. Straty wody i sposoby ich obnizahia, Ochrona Srodowiska (in Poland).

14. Chejlitko A.A., 2014. Opredelenie kojefficienta teploprovodnosti poristyh metallicheskih izdelij. Nauchnyj vestnik, Tambov, OOO Konsaltingovaja kompanija Jukom, Vol.1, 111-118 (in Russian).

15. Goncharuk V.V., 2011. Perspektivy razvitija fundamental'nyh i prikladnyh issledovanij $\mathrm{v}$ oblasti fiziki, himii i biologii vod Kyiv, Naukova dumka, 407 (in Russian).

16. Korchemljuk M.V., 2016. Ekologichni naslidki global'nih klimatichnih zmin/ M.V.Korchemljuk Ekologichni naslidki global'nih klimatichnih zmin. Naukovij visnik IFTUNG: naukovo-tehnichnij zhurnal, No.1(13), 120-129 (in Ukrainian).

17. Martazinova V., 2002. Zminy $\mathrm{v}$ climati Ukrainy. Geographiya ta osnovy ekonomiky v shkoli, No.1(25), 31-33 (In Ukraininan).

18. Gavich I.K., 1980. Teoriya I praktika primeneniya modelirovaniya $\mathrm{v}$ gidrogeologii. Moskow, Nedra, 358 (in Russian).

19. Kuprienko P., Lapowska S., Kuprienko N, 2017. Nanomodified natural aluminum silicates in technology treatment of industrial waste and the production of building materials. Underwater Technologies, Iss.05, 74-83.

20. Nadutyi V., Chelyschkina V., Kostyrya S., 2016. Analysis of the integrated dewatering of fine fractions of granite. Underwater Technologies, Iss.03, 41-46 (in Russian). 


\section{Моделирование надежности работы замкну- той системы водоснабжения в условиях глобального потепления}

\section{Алексей Назаренко}

Аннотация. Изучаются вопросы повторного использования воды в рекреационных целях предприятий. Органичная система предприятия может быть адаптированной системой водоснабжения, герметично закрытой и оснащенной автоматическими датчиками, во всех смыслах. Также целесообразно использовать дистанционное управление параметрами теплового процесса на участках с использованием модулей GPS. Важность корпоративного акцента заключается в создании социальной ответственности для сервис-менеджеров и механиков для каждого ресурсосберегающего действия и будущих экономических предпочтений.

Наиболее перспективным и социально мотивированным направлением рециклинга является моделирование баланса различных потоков воды с учетом качества химических компонентов [1].

В настоящее время граждане и администрация технопарков оценивают чистую воду для таких показателей:

- безопасность воды (санитарно-эпидемиологические требования);

- наличие воды (количество и качество);

- стабильность качества воды (вода для экосистем, вода для здоровья, вода для устойчивого развития);

- изменение климата и водная безопасность.
Для соответствия этим показателям, были проведены эксперименты для разных режимов работы производственного оборудования.

Таким образом, для определения оптимального количества пресной воды использовался центральный ортогональный композиционный план второго порядка.

Математическая модель получена в ходе научного эксперимента

Моделирование системы с учетом жесткости воды $(1,5 \ldots 10,5$ мг-экв/л), щелочности воды (1,5..10 мг-экв/л) дает прогнозные данные о допустимом коэффициенте испарения циркулирующей воды.

На основе этого моделирования рекомендуется рекомендовать подготовку искусственного источника питания с жесткостью воды 1,5 мгэкв/л на предприятиях. Это позволит системе работать при коэффициенте испарения 2,55 и сохранить объем свежей воды, равный производственному циклу.

Использование сельскохозяйственных отходов (хитозан) показывает возможность использования для очистки сточных вод в промышленных циклах.

Этот же раствор можно использовать для питания овощных и декоративных культур, в местном сельскохозяйственном ландшафте предприятия. Развитие дочернего производства, позволяет расширить ассортимент продукции и улучшить имидж компании.

Ключевые слова: баланс, коэффициент водопользования, повторная вода, коэффициент упаривания, подпитка системы, жесткость. 